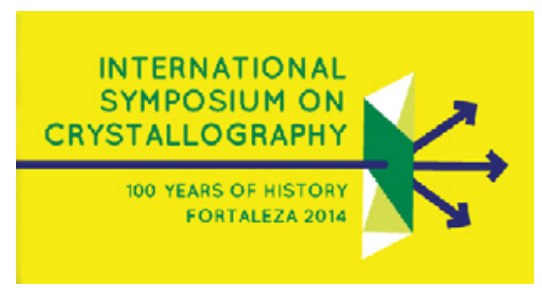

\title{
HISTORY OF CRYSTALLOGRAPHY IN BRAZIL
}

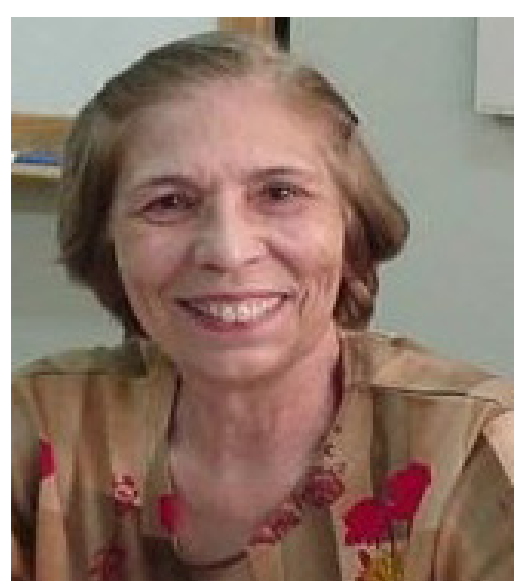

\author{
Yvonne Primerano Mascarenhas \\ Crystallography Laboratory, Institute of Physics of São Carlos, USP/Campus of São Carlos
}

Before the discovery of the X- ray diffraction by von Laue in 1912 crystallography in Brazil, as well as in Europe, was limited to the study of the symmetry and morphology of crystals, mainly of minerals. Jose Bonifácio de Andrade and Silva, native of Santos, São Paulo, Brazil (1763-1838) considered the first geologist and mineralogist of Brazil and Portugal, after his initial studies in São Paulo completed his education in Portugal and improved his formation travelling and working during about ten years to several countries (EEUU, France, Germany and Sweden). During the troublesome years of the French revolution he did his mineralogical training in the School of Mines of Paris under orientation of René-Just Haüy, the founder of Crystallography and presented to the Société d' Histoire Naturelle de Paris an interesting work entitled Mémoire sur les diamants du Brésil. James Dwigt Dana (1813-1895), author of System of Mineralogy, named in his honor andradite, a new mineral of the group of the garnets. Even after the brilliant discovery carried by von Laue the crystallographers faced enormous difficulties for the determination of molecular crystalline structures due to the well known Phase Problem and, the first efficient method for its solution only appeared in the middle of the thirties with the discovery of the heavy atom method by Patterson. Only quite later, in the sixties, Karle and Hauptmann introduced the direct methods. Aware of the extraordinary scientific results of Crystallography in Europe and USA the interest of some Brazilian scientists was raised for the introduction of the crystallographic methods in Brazil. Thus by the occasion of the fortieth anniversary of the discovery of X-ray diffraction (1952) a group of eminent scientists congregated in a session of the Brazilian Academy of Sciences to present the important areas of application of Crystallography with sights to its introduction in Brazil. Nevertheless more eight years would be necessary for someone decide to dedicate oneself to crystallography when I, and then my husband Sergio Mascarenhas, were awarded with a Fullbright scholarship and spent about1 8 months in Pittsburgh, USA, he doing experimental work in Solid State Physics at Carnegie Tech., and myself in X-ray diffraction structural crystallography at the Department of Crystallography of the University of Pittsburgh. The success reached after our return to São Carlos was only possible due to the enthusiasm of many students and collaborators who joined our group of research. We can say that Crystallography and Solid State Physics, today called Condensed Matter Physics, are well established in Brazil. It noticeable the creation of many well equipped laboratories spread all over Brazil and the creation of National Laboratories as the Brazilian Synchrotron Light Laboratory (LNLS) for use, not only by the Brazilian crystallographic community, but also by other Latin-American countries. However, new extraordinary perspectives had recently appeared abroad with the X-ray free electron laser that already is allowing the determination of protein crystal structures using nanocrystals with data harvested in femto seconds! (Fento second X-ray Protein Nanocrystallography, Chapman et al., Nature (2011), 73-73). 